\title{
Impact of inductive and selective agents on biosynthesis of the new anti-staphylococcal antibiotic batumin
}

\author{
L. N. Churkina, A. N. Kravets, V. V. Klochko \\ Institute of microbiology and virology, NAS of Ukraine \\ 154, Acad. Zabolotny Str., Kyiv, 03143, Ukraine \\ churkina@imv.kiev.ua
}

\begin{abstract}
Application of high concentrations of antistaphylococcal antibiotic batumin in order to increase biosynthetic activity of the own antibiotic producing strain allowed selecting variants with increased productivity. Clone Pseudomonas batumic No.9 with maximum activity synthesized from 60 to $70 \mathrm{mg}$ of batumin per l of culture medium, which was 2 times higher than the activity of the most productive natural producing strain However, after storage of this culture in non-selective conditions we noticed gradual decrease in the activity. Chlortetracyclin possesses only selective influence, the result of which was raise in the content of clones with the increased activity in producing strain population.
\end{abstract}

Key words: batumin, chlortetracycline, antibiotic producing strain, S. aureus

Introduction. Antibiotic batumin had been isolated from the "Pseudomonas batumic" in the Institute of Microbiology and Virology of National Academy of Sciences of Ukraine. Chemical structure of batumin was shown to be (2E, 10Z, 12E)-20-(3aminocarboxy-2-methyl-1-oxybutyl)-amino-7-methyl ene-17-oxo-19-oxy-3,5,15-trimethyl-eicosa-2,10,12-tr ienoic acid [1]. Due to its unique chemical structure, batumin can be considered as new antimicrobial compound with no analogues among commonly used antibiotics. Batumin has unique and selective activity against all investigated types of staphylococci [2, 3], and is considered to be a highly effective therapeutic agent for the treatment of nasal staphylococcus carriage $[4,5]$.

The diagnostic preparation "Diastaph" (batumin impregnated disks) ensures quick and reliable

(C) L. N. CHURKINA, A. N. KRAVETS, V. V. KLOCHKO, 2007 identification of microorganisms of genus Staphylococcus [6]. The disks may be successfully used when providing regular hospital examination on nasal carriage of staphylococci. There are enough evidences to consider batumin as a promising therapeutic agent against hospital staphylococcal infections - one of the most urgent and yet not solved problems of modern medicine. Some disadvantages of natural antibiotic producing strain, is a low level of antibiotic biosynthesis (20-25 mg/l), which creates serious obstacles on the way to its industrial production.

The use of antibiotics as selective and inducing agents allowed obtaining some practically important results. Thus, highly active mutants of ristomycin, chlortetracycline, and imbricin producing strains were selected under the influence of antibiotics on producing cultures of actinomyces [9-12].

The goal of current work was to investigate the specificities of batumin and chlortetracycline effects on 
biosynthetic activity of antibiotic producing strain with the purpose of increasing of its productivity.

Materials and Methods. The strain "P. batumici" 109 with increased biosynthetic activity has been used throughout the study [7]. It is a derivative of wild strain "P. batumici" B-303, selected among the clones during passages of the parental strain. Batumin and tetracycline resistant variants of "P. batumici" 109 were obtained using the method of step-wise selection with increasing antibiotics concentration. The agar-containing media was supplemented with batumin and chlortetracycline dissolved in water. Minimal inhibiting concentration (MIC) of batumin and chlortetracycline for "P. batumici" 109 were $200 \mathrm{Mg} / \mathrm{ml}$ and $0.2 \mathrm{mg} / \mathrm{ml}$, respectively.

"P. batumici" 109 and batumin-resistant variants No.4 and No.9 and chlortetracycline-resistant variants No, 28, 53, and 80 were kept in non-selective conditions layered with mineral oil on $0.5 \%$ of MPA. To study the changes in antibiotic production, all " $P$. batumici" variants were inoculated at the density of $1 \mathrm{C} 10^{7}$ cells per $\mathrm{ml}$ into $150 \mathrm{ml}$ of synthetic growth media The cultivation was performed using a shaker $(220 \mathrm{rpm})$ in Erlenmeyer flasks $(750 \mathrm{ml})$ at the following conditions: $150 \mathrm{ml}$ of nutrition medium, initial concentration of cells was $1 \mathrm{C}^{7} 0^{7}$ cells per $\mathrm{ml}, \mathrm{T}=$ $25^{\circ} \mathrm{C}$, cultivation time -72 hours.

Biosynthetic activity of "P. batumici" clones was assessed using the worked-out method on MPA with the replicator, calculating for 5 clones per cup, using batumin-highly sensitive test-culture of Staphylococcus aureus 209 P (UKM B-918, ATCC $6538 \mathrm{P})$, i.e. using the method of batumin diffusion into agar.

Based on the diameter of zone of growth inhibition of test Staphylococcus aureus 209 P, clones were sub-divided as low-active - with 5-20 mm zone of inhibition, active $-20-30 \mathrm{~mm}$, with increased activity $30-40 \mathrm{~mm}$, and highly active $-40-60 \mathrm{~mm}$.

Quantitative concentrations of antibiotic in cultural medium were determined by spectrophotometry. Cultural medium was extracted by chloroform. Obtained extract was steamed in vacuum-steamer at $40-45^{\circ} \mathrm{C}$ with the following purification using the method of thin-layer chromatography. Batumin containing sorbent was removed from chromatographic plate and eluted with alcohol. Batumin concentration in the solution obtained was determined using the method of spectrophotometry and calculated according to the following formula [8]:

$$
C=\frac{D^{*} P^{*} 10^{4}}{E^{1 \%}}
$$

where: $C$ - batumin concentration, $\mathrm{mg} / \mathrm{l} ; D$ - optical density of the batumin solution at $\lambda=225 \mathrm{~nm}$; $\mathrm{P}$ - total dilution of the sample; $E^{1 \%}$ - extinction coefficient of $1 \%$ batumin solution $\left(E^{1 \%}=584\right) ; 10^{4}-$ concentration recalculation coefficient per 11 of cultural medium.

Results and Discussion. The possibility of increasing batumin synthesis using the target product in selection was studied at the first stage of our work. Using the method of stepwise selection, the variants of " $P$. batumici" 109 resistant to different batumin concentrations $(400,800,1200$, and $2000 \mathrm{mkg} / \mathrm{ml})$ were obtained, which was necessary in order to analyse the dependence of their productivity on the level of resistance to own antibiotic. According to hypothesis there was a direct correlation between the productive cell and the ability to grow on higher antibiotic concentrations, thus, the most productive cells would grow on the highest concentrations.

It was found that the rate of bacterial survival decreased along the concentration increase from 200 to up to $2000 \mathrm{mkg} / \mathrm{ml}$. Single clones with the level survival of $0.05 \%$ were formed at the concentration of $2000 \mathrm{mkg} / \mathrm{ml}$. Batumin-resistant colonies were different from corresponding batumin-sensitive colonies by a number of morphological characteristics, namely, they were rough, of smaller size, and some of them were mucous. Next, 1359 clones were selected for further experiments.

The analysis of "P. batumici" 109 clones for synthesis of antibiotics revealed uneven level of antibiotic biosynthesis by some cells. The populations were dominatd by active clones $(46.7 \pm 3.1 \%)$ and the

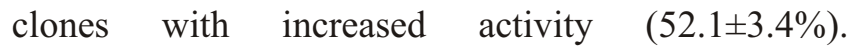
Batumin-resistant variants demonstrated dependency between the level of specific activity and the level of antibiotic resistance. The increase in batumin resistance level was followed by the increased number of clones with increased activity and highly active clones as well (Fig.1). It is noteworthy that within the concentration 


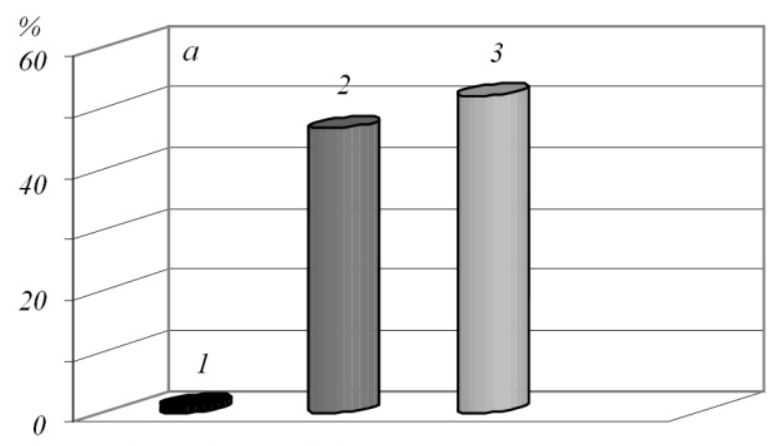

Distribution of clones according to their activity

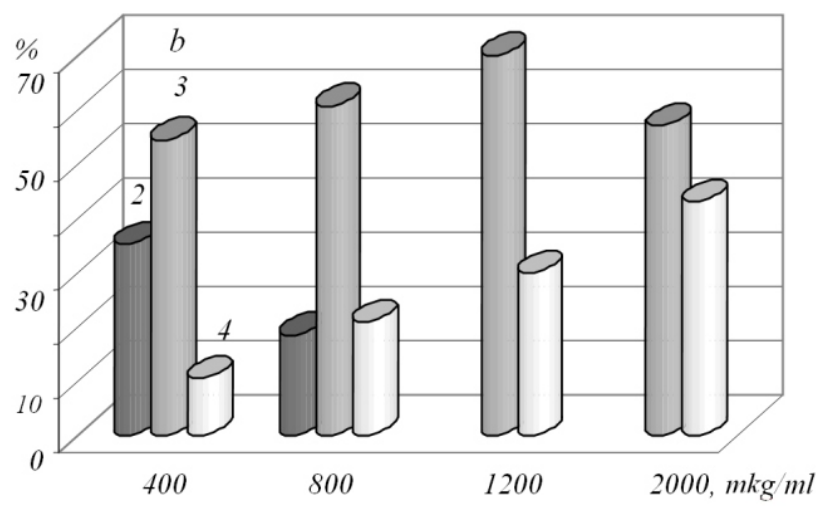

Fig.1 Variability of activity degree of "P. batumici" 109 clones, induced with batumin: 1 - low active; 2 - active; $3-$ increased activity; 4 - highly-active ( $a$ - before selection, $b-$ after selection)

range from 1200 to $2000 \mathrm{mkg} / \mathrm{ml}$, active variants had been replaced by highly active clones.

It has been assumed that the variants with the highest batumin-resistance have to be of increased biosynthetic activity. The search for maximally active variants was performed among 453 highly active clones, obtained in five independent experiments and different in the level of resistance to antibiotic. The largest growth inhibition zones of S. aureus 209P (47 and $58 \mathrm{~mm}$ ) had been given by two clones, No.4 and No.9, with the level of resistance $2000 \mathrm{mkg} / \mathrm{ml}$ (Fig.2). These clones were synthesised at the level of 52-58 and 65-70 mg/l of antibiotic, respectively. Therefore, comparing to the parental strain of "P. batumici" (batumin output $31.4 \pm 1.9 \mathrm{mg} / \mathrm{l}$ ), the selected variants of"P. batumici" No.4 and No.9 had average 2-2.5 times increase in the yield of antibiotic.

As the stability of level of antibiotic synthesis is of great practical importance, we have investigated the stability of variant No.9 after storing for 20 and 60 days. When the stocks were plated to obtained independent clones, it was found that the significant variations of specific activities in their populations. of batumin-resistant highly-active clone No.9 to single clones revealed their significant activity-wise distribution.

Thus, after 20 days the clones with increased activity $(71 \pm 2.5 \%)$ and highly-active ones $(29 \pm 1.4 \%)$ dominated, while after 60 days this ratio had been changed, and the clones with increased activity $(53.7 \pm 2.1)$ and active clones ( $43.5 \pm 1.9 \%$ ) began to prevail in population dominant with diminishing of highly-active clones to $2.8 \pm 0.004 \%$ (Fig.3).

These ratios were observed on storing of the clones on batumin-free medium, i.e. gradual decrease in activity was observed in the course of storing. The culture achieved its initial state and synthesised 35-40 $\mathrm{mg} / \mathrm{l}$ of batumin. Similar situation was observed when investigating the stability of variant No.4.

The experiments performed show that batumin may be used for increasing the biosynthetic activity of antibiotic producing strain of its own. However, it is worth mentioning that obtained highly-active clones are characterized by relative stability and, therefore, can be used for obtaining of antibiotic at the laboratory conditions only.

Taking into account the information on successful application of other types of antibiotics in order to increase the level of target product output, we decided to study the influence of chlortetracycline on batumin synthesis. Tetracyclines belong to the class of antibiotics which inhibit protein synthesis by means of modification of proteins of translational apparatus of target cell [13, 14], and batumin belongs to membrane-acting antibiotics [15, 16], therefore, the manner of action of these antibiotics on antibiotic producing strain cells will be different.

"P. batumici" 109 variants, resistant to different concentrations of chlortetracycline $(2,20,40 \mathrm{mkg} / \mathrm{ml})$ were obtained using the method of step-wise selection. Preliminary experiments were dedicated to the study of survivability of "P. batumici" 109 cells depending on the level of resistance. As it has been supposed, increase in resistance of chlortetracycline resulted in significant decrease in survivability of producing strain 

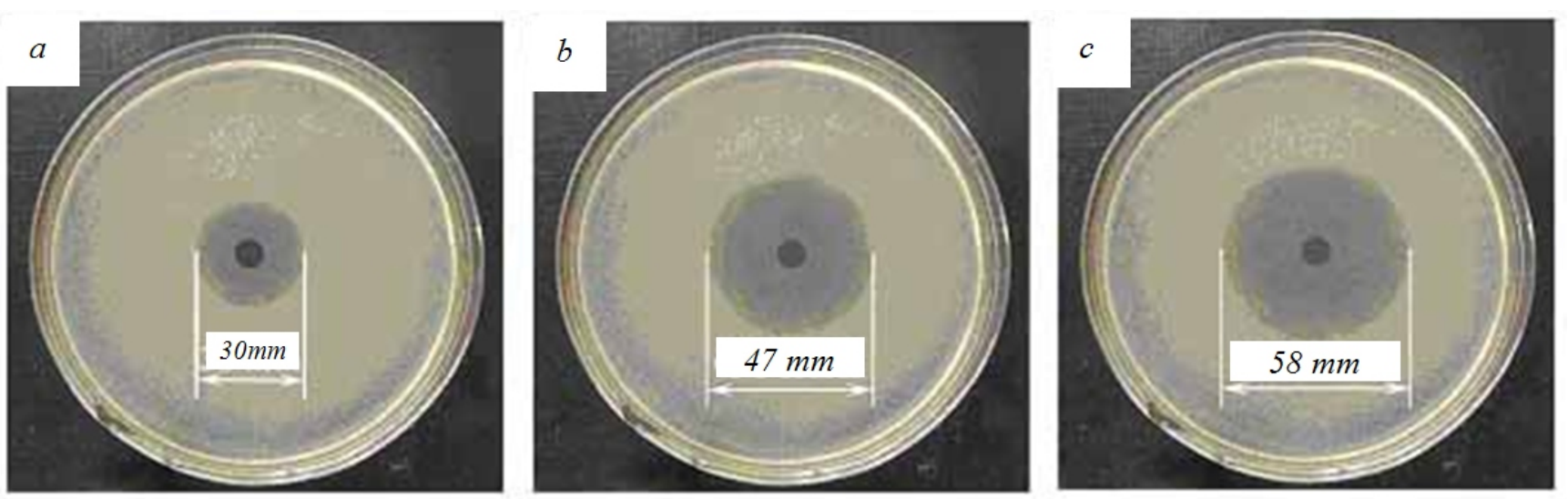

Fig.2 The growth inhibition zones of test-culture $S$. aureus 209P: $a$ - "P. batumici" 109; $b$, $c$ - batumin resistant variants of clones No.4 and No.9 with increased level of antibiotic biosynthesis

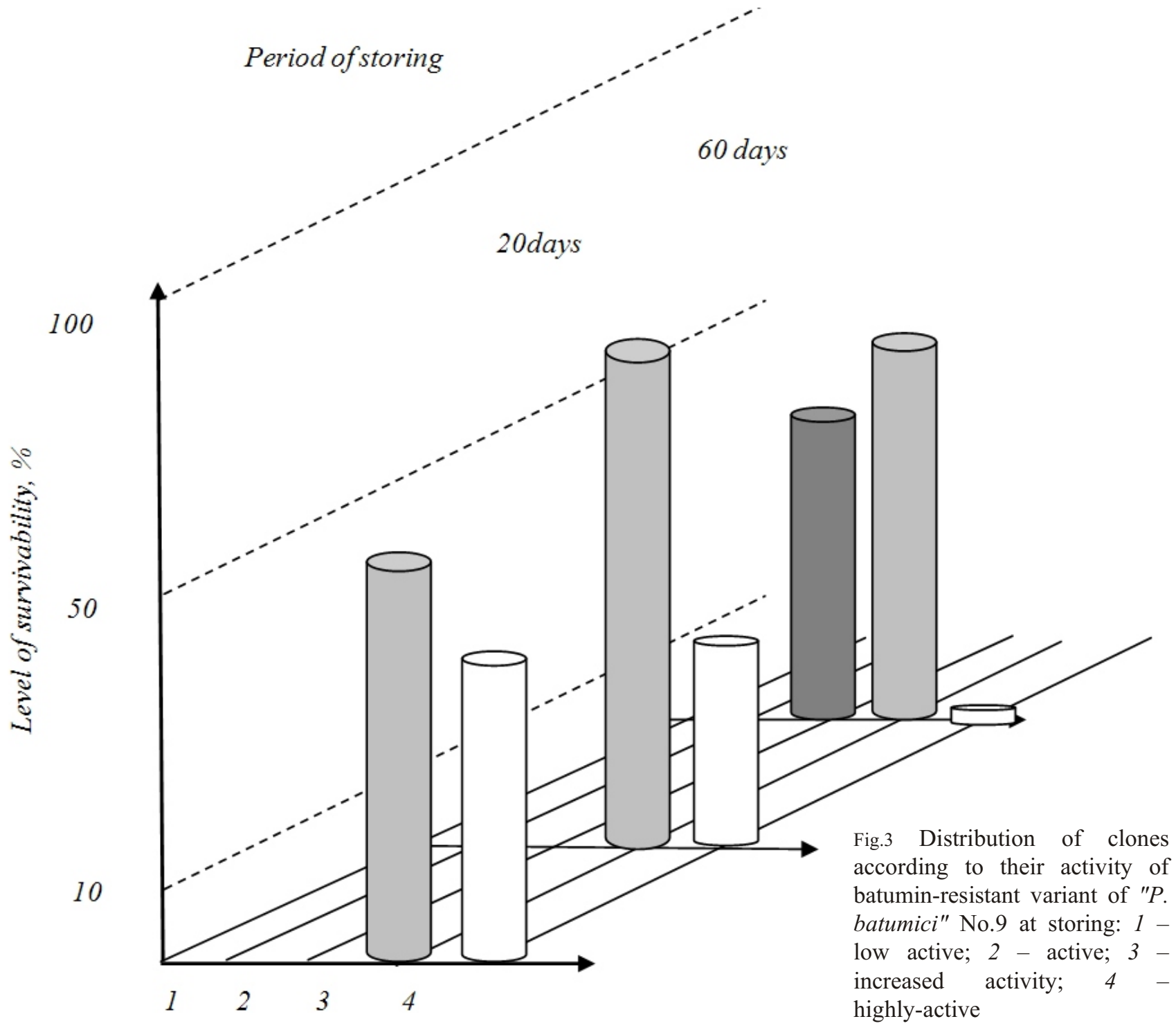


Table The percentage distribution of specific activity among individual clones in population of "P. batumici" 109 after chlortetracycline effect

\begin{tabular}{c|c|c|c|c}
\hline \multirow{2}{*}{$\begin{array}{c}\text { Chlortetracycline } \\
\text { concentration, } \\
\mathrm{Mg} / \mathrm{ml}\end{array}$} & \multirow{2}{*}{$\begin{array}{c}\text { The number of } \\
\text { clones reviewed }\end{array}$} & Low active & Active & Increased activity \\
\cline { 3 - 5 } Control & 105 & $1.2 \pm 0.06$ & $46.7 \pm 2.8$ & $52.1 \pm 3.1$ \\
2 & 122 & 0 & $47.5 \pm 2.9$ & $52.5 \pm 3.0$ \\
20 & 125 & 0 & $24.7 \pm 1.5$ & $75.3 \pm 4.1$ \\
40 & 118 & 0 & $10.8 \pm 0.9$ & $89.2 \pm 5.0$ \\
\hline
\end{tabular}

cells. At the concentration of antibiotics of $2 \mathrm{Mkg} / \mathrm{ml}$, the number of survived bacteria amounted to $8 \%$, and at the concentration of 20 and $40 \mathrm{mkg} / \mathrm{ml}, 0.8 \%$ and $0.05 \%$ of bacteria survived, respectively.

The results of investigation of correlation of antibiotic producing strain clones according to the degree of their activity at the interaction with chlortetracycline showed significant increase in population of clones with increased activity and decrease in number of active clones. Meanwhile, in the population of "P. batumici", highly-active clones were not detected (Table).

Further research was to study the influence of maximally active clones according to batumin synthesis among the clones with increased activity and the level of survivability of 0.8 and $0.05 \% .760$ clones of resistant to chlortetracycline variants (20 and 40 $\mathrm{Mkg} / \mathrm{ml}$ ) were selected for further research. Differential analysis of clones according to batumin synthesis allowed detecting three clones - No.28, 53 and 80 with diameter of zone of growth inhibition S. aureus $209 \mathrm{P}$, 39,35 , and $37 \mathrm{~mm}$, respectively, in comparison with 30 mm of "P. batumici" 109. The productivity of these clones was $35-40 \mathrm{mg} / \mathrm{l}$ of batumin, which did not exceed significantly biosynthetic activity of "P. batumici" 109.

Although among chlortetracycline-resistant variants of "P. batumici" 109 we did not reveal the clones with increased biosynthetic activity, antibiotic possessed certain selective activity, which consisted in purifying natural population from low active and active clones.
Antibiotics are often referred to as cytotoxic metabolites for bacteria that produce them. The resistance of many antibiotic producing strain towards them is determined by energy-dependent efflux systems, which carry toxic products out of the cell [17-20]. It is worth mentioning that the increase in activity of such systems may cause the increase in antibiotic output. In particular, it has been demonstrated for 6-dimethylchlortetracycline [21], surfactin and pliplastin [22], fenarimol and penicillin [23], cephalosporin C [24].

To our mind, the increase in antibiotic output at selective passages of culture on the media with increased batumin concentrations is determined by its more active removal out of the cell, which is the main mechanism of producing strain detoxication for its toxic product. It is also possible that the synthesis of antibiotic increases in accordance to the feedback mechanism, but the solution to this problem is far beyond the framework of this work.

Positive chlortetracycline effect may be due to the selection of cells with highly-active efflux pumps. It is possible that "P. batumici" uses a special pump for batumin removal, which is in good correlation with different effects of batumin and chlortetracycline presence in growth medium.

Therefore, having investigated the effect of batumin and chlortetracycline on biosynthetic activity of antibiotic producing strain, it has been shown that batumin initiates the appearance of highly-active clones with increased productivity in "P. batumici" 109 population, while chlortetracycline is specific for its 
selective activity only, as a result of which the number of clones with increased activity increases.

Conclusions. For the first time, the possibility of increasing the synthesis, using the selection of the target product, has been shown for producing strain of anti-staphylococcal antibiotic batumin.

The use of batumin in selection of antibiotic producing strain allowed obtaining a relatively stable producing strain with batumin output more than 2 -fold increased.

During selection of antibiotic producing strain with chlortetracycline, highly-active clones have not been detected, however, the effect of this antibiotic in population of producing strain population revealed the decrease in the number of low active and active clones and the increase in the number of clones with increased activity. Chlortetracycline was shown to be of selective activity, purifying natural population from low active and active clones.

\section{Л. Н. Чуркина, А. Н. Кравец, В. В. Клочко}

Влияние индуцирующих и селективных агентов на биосинтез нового антистафилококкового антибиотика батумина

\section{Резюме}

Использование высоких концентраций антистафилококкового антибиотика батумина для повышения биосинтетической активности собственного штамма-продуцента позволило отобрать варианты $c$ повышенной продуктивностью. Максимально активный клон Pseudomonas batumici №9 синтезировал 60-70 мг/л батумина, что в 2 раза превышало активность наиболее продуктивного природного штамма. Однако при хранении этой культуры в неселективных условиях наблюдалась постепенная потеря активности. Хлортетраџиклин, использованный для увеличения выхода батумина, обладал селективным действием, в результате чего возрастало содержание клонов с повыменной активностью.

Ключевые слова: батумин, хлортетрациклин, итамм-продуцент, Staphylococcus aureus.

\section{REFERENCES:}

1.Esipov S. E., Kiprianova E. A. Batumin, a novel antibiotic produce by Pseudomonas batumici nov. sp. 3187 // 5th Int. Conf. on Chemical Synthesis of Antibiotics and Related Microbial Products: Abstr.-Budapest: Hung. Acad. Sci. publ., 1996.-P. 14.

2.Смірнов В. В., Чуркіна Л. М., Носенко Г. А., Бідненко С. І., Артисюк О.І., Пустовалова Л. І., Кіпріанова О. А., Гарагуля О. Д. Ефективність діагностичних дисків з батуміном при ідентифікації та індикації стафілококів // Лікарська справа.—2002.—№ 5-6.-C. 27-31.

3.Witte W., Cuny C., Mollmann W. U. In vitro - Wirksamkeit von Batumin auf Staphylococcus aureus // Chemother. J.-1997.-6.-P. 48-50.
4.Smirnov V. V., Churkina L. N., Kiprianova E. A. Antibiotic batumin for diagnostics of staphylococci and treatment of Staphylococcus aureus nasal carriage Poster presentation // 10th Int. Symp. on Staphylococci and Staphylococcal infections: Abstr.- Tsukuba, 2002.-P. 130.

5.Смирнов В. В., Киприанова Е. А., Чуркина Л. Н. Антибиотик батумин в борьбе с госпитальной стафилококковой инфекцией // Междунар. науч. конф. «Актуальные вопросы борьбы с инфекционными болезнями».-Харьков, 2003.-С. 152.

6.Смирнов В. В., Киприанова Е. А., Гвоздяк О. Р., Гарагуля А. Д., Чуркина Л. Н., Проскурякова Н. Б., Харченко Л. А. Использование дисков с батумином для экспресс-идентификации стафилококков // Журн. микробиологии, эпидемиологии и иммунологии.-1999.—№ 5.-С. 77-80.

7.Смирнов В. В., Чуркина Л. Н., Кравеи А. Н., Гарагуля А. Д. Некоторые особенности биосинтеза нового антистафилококкового антибиотика батумина // Антибиотики и химиотерапия.-1993.-38, № 4-5.-С. 3-5.

8.Смирнов В. В., Чуркина Л. Н., Перепныххатка В. И., Муквич Н. С., Гарагуля А. Д., Киприанова Е. А., Кравеи А. Н., Довженко С. А. Получение высокоактивного штамма-продуцента антистафилококкового антибиотика батумина // Прикл. биохимия и микробиология.-2000.-36, № 1.-С. 55-58.

9.Тренина Г. А., Трутнева Е. М. Использование ристомицина при селекции активных вариантов Proactinomyces Fructiferi var. Ristomycini // Антибиотики.-1966.-№ 9.-С. 770-774.

10.Веселова С. И. Сравнительное изучение летального, селективного и мутагенного действия хлортетрациклина, окситетрациклина и стрептомицина на Actinomyces aureofaciens и Actinomyces rimosus. 1. Летальное и селективное действие хлортетрациклина, окситетрациклина на Actinomyces aureofaciens и Actinomyces rimosus // Генетика.—1967.—№ 12.—С. 73-79.

11.Hotta K., Takamura S. Visualization of potential antibiotic productivity of actinomycetes: Effect of antibiotics, amino acid analogues and shifp-down // ISBA'94: Int. Symp. Biol. Actinomycet.-Moscow, 1994.-P. 168.

12.Горбунова Н. А., Яковлева Е. П. Действие собственного антибиотика на продуцент имбрицина при выращивании на агаризованной среде // Антибиотики и химиотерапия.-2000.-45, № 5.-C. $6-8$.

13.Schnappinger $D$, Hillen $W$. Tetracyclines: antibiotic action, uptake, and resistance mechanisms // Arch. Microbiol._1996._165.-P. $359-369$.

14.Brodersen D. E., Clemons W. M. Jr., Carter A. P., Warren R. J., Wimberly B. T., Ramakrishnan $V$. The structural basis for the action of the antibiotics tetracycline, pactamycin, and hygromycin B on the 30S ribosomal subunit // Cell.-2000.-103.-P. 1143-1154.

15.Смирнов В. В., Васюренко 3. П., Чуркина Л. Н. Липиды // Стафилококки.-Киев: Наук. думка, 1988.-С. 34-65.

16.Смирнов В. В., Чуркина Л. Н., Васюренко 3. П. Индукция антибиотиком АЛ-87 изменений в жирно-кислотном составе фосфолипидов и нейтральных липидов чувствительного к нему штамма Staphylococcus aureus 209P // Антибиотики и химиотерапия.-1988.-33, № 6.-С. $440-443$.

17.Cundliffe E. How antibiotic-producing organisms avoid sucide // Annu. Rev. Micobiol.-1989._43.-P. 207-233.

18.Ma Y., Patel J., Parry R. J. A novel valanimycin-resistance determinant (vlmF) from Sreptomyces viridifaciens MG456-hF10 // Microbiology.-2000.-146.-P. 345-352.

19.Ryan B. M., Dougherty T. J., Beaulieu D., Chuang J., Dougherty B. A., Barrett J. F. Efflux in bacteria: what do we really know about it? // Expert Opin Invest. Drugs.-2001.-10.-P. 1409-1422.

20.Skatrud P. L. The impact of multiple drug resistance (MDR) proteins on chemotherapy and drug discovery // Prog. Drug. Res.-2002.-58.-P. 99-131.

21.Dairi T., Aisaka K., Katsumata R., Hasegawa M. A self-defence gene homologous to tetracycline effluxing gene essential for antibiotic 
production in Sreptomyces aureofaciens // Biosci. Biotechnol. Biochem.-1995.-59.-P. 1835-1841.

22.Turner M. S., Helmann J. D. Mutations in multidrug efflux homologs, sugar isomerases, and antimicrobial biosynthesis genes differentially elevate activity of the sigmaX and sigmaW factors in Bacillus subtilis // J. Bacteriol.-2000.-182.-P. 5202-5210.

23.Andrade A. C., Van Nistelrooy J. G., Peery R. B., Skatrud P. L., De Waard M. A. The role of ABC transporters from Aspergillus nidulans in protection against cytotoxic agents and in antibiotic production // Mol. and Gen. Genet.-2000.-263.-P. 966-977.
24.Ullan R.V., Liu G., Casqueiro J., Gutierrez S., Banuelos O., Martin J.F. The cefT gene of Acremonium chrysogenum $\mathrm{C} 10$ encodes a putative multidrug efflux pump protein that significantly increases cephalosporin C production // Mol. Genet. Genom.-2002.-267.-P. 673-683.

ҰдК 615.33.015.4:579.861.2.87 